\title{
e-health business models prototyping by incremental design
}

\author{
Josep Ma. Monguet, Eduardo Huerta, Joaquín Fernández, Marco Ferruzca, Susana \\ Badillo.
}

\begin{abstract}
Internet and IT among other innovative drivers push companies to update their business models, and design stands out as an emergent issue strongly connected with innovation, which, in turn, is the main resource of the modern economy. One way to achieve innovation is through artifacts that allow the development of successful information systems in organizations.
\end{abstract}

Moreover, the field of health appears as a sector with many opportunities to improve services through IT and design. Therefore, e-health comes out as one of the elements that should eventually help in the evolution of business models in health systems.

In this chapter we present a design method of IT artifacts for e-health adapted from the method proposed by Pahl and Beitz (1995). The correctness of the design method adopted is a significant issue to generate new business models successfully or to adapt the existing ones in health systems.

\section{INTRODUCTION}

Many health institutions are nowadays involved in e-health projects that envision the application of internet and IT to improve their activity. This is traduced, from one side, in opportunities for multidisciplinary research and, in the other, is a chance to evolve some of the current business models in health.

e-health can become one of the main areas for e-business development in the future years, "thanks to information technologies have been touted as both a solution to rising health care costs and a way to reduce medical errors" (Adler-Milstein, 2009). In fact, IT investment is central to President Obama's vision for health care reform in the USA and his estimates of the savings from it have been substantial (Adler-Milstein, 2009). A similar view exists in Europe where e-health is one of the central items of the European Commission Agenda. The huge investments expected all and around the world will turn ehealth in a fruitful field for opportunities, where final success of many of them will depend on business models innovation.

The work presented in this chapter, based in the collaboration between health institutions, an internet company and a technical university, allow testing a methodology to design and develop internet artifacts for e-health, considering the business model evolution from the beginning.

The work is founded on the desk analysis of current paradigms of design management and relays on a field experience based in the application of the proposed methodology to a 9 e-health prototypes created during the period 2006 - 2009. The last one, a tele-rehabilitation system named E-DIS, is used to illustrate the design methodology proposed. 


\section{BACKGROUND}

\section{The e-health area. Expectations and difficulties}

Despite the enormous investment, both public and private, in health innovation and the magnitude of the opportunity to both do good and do well, too many efforts fail, losing billions of investor dollars along the way (Herzlinger, 2006). Innovative solutions involving internet and multimedia systems should facilitate the renovation of health care business models that are a focal aspect of problems in the health systems. ICT may help with new products and services, to develop new treatments and to improve existing ones, and it is also a tool that may improve the processes. In the e-health sector, successful innovation and the development of real health services arising from that innovation is not easy, has to be gradual, and must be connected with the evolution of health business models.

Technology in health allows record, measure, monitor, manage and provide guidance to the patient, together with the opportunity to offer care services through the Internet in real time (June Chuan Su, 2007). Telemedicine systems have enabled to maximize the collection, delivery and communication of medical information, clinical messaging, interaction with nurses and medical records (Maheu, Whitten and Allen, 2001), beside facilitates the exchange of information between doctors and patients. In short, the establishment of telemedicine systems encourages the integration of many activities in e-health clinics but also means dealing with a lot of data, information and resources (June Chuan Su, 2007). It also means having the obligation to have information systems commensurate with the importance of the task they perform. With a successful information system, allowing both to medical staff and patients to focus on other activities and, with this, translate effort and time into valuable medical resources.

The e-health sector appears as a huge market but largely untapped (European Commision, 2008). One of the main reasons for the health service providers not to invest in IT, could be the lack of common standards between countries and interoperability problems. One consequence of the lack of investment is that the growth in companies supplying ICT for health sector is smaller than it could be (European Commision, 2008).

As the high risks would limit the private investments public administrations have to do extra efforts to encourage both sides of the market, offer and demand. Both in USA and Europe, the administration is expected to invest strongly in the technology sector oriented to health services for two reasons: the improvements that can be introduced into medical terms, and the money that should be saved through IT. Let's consider, for example, the adoption of electronic health records, -EHRs- by most doctors and hospitals will mean savings of up to 77 billion dollars annually in USA. Moreover, Medicare, the largest payer in the United States, has introduced the first financial incentive for doctors who adopt health IT (Adler-Milstein, 2009).

In terms of quality in providing medical services, there are still some problems arising from the adoption of technology that have not been resolved, such as the lack of integration of information systems may hamper the access of doctors and nurses to patient data. Recognizing that, the introduction of IT in health care is something that can not be avoided. In fact, there are health care organizations who believe that gains will flow from the technology alone. For example, it is expected that practices such as adoption of electronic health records to improve the doctors workflow, accuracy, communication with patients, access to medical history and clinical decision making (Adler-Milstein, 2009).

It is also true that, to embrace the new capabilities offered by the IT, organizations need to implement substantial changes, such as increasing training for employees and individual decision-making authority. 
This "flattened their hierarchies, made greater use of skilled, decentralized teams and raises incentives for team performance” (Adler-Milstein, 2009). All this represents a major challenge for organizations providing health services, because as well as making big investments, it suppose workers are skilled and opened to receive these updates. Moreover, it is natural to expect that any innovation in information systems necessarily bring economic benefits to the organization. According Hevner (et al, 2004) such information systems IT improves economic performance through the effectiveness and efficiency.

\section{Design as an integrative tool for e-health-business development}

Design is deeply connected with innovation (Hollanders \& Van Cruysen, 2009), which, in turn, is one if not the the principal driver of the modern economy (Purao, 2008). One way to achieve innovation is through artifacts that allow the development of successful information systems in organizations (March et al, 2008). For the successful implementation of new information systems and IT artifacts in organizations -whether for health or any business-, design emerges as a powerful integrating agent.

From the economic point of view, we can say that products and services that are results of design are the core of the economic system. Furthermore, innovations, the main source of wealth in modern economies are precisely design changes or advances in design (Purao, 2008).

According Gui Bonsiepe (2000), the main task of design is not to produce knowledge, as many believe, but "to present" knowledge. That is, develop information systems capable of delivering knowledge in a clear way and without giving chance to second readings. This is linked to the functional task of design, in the sense of making the artifact or object efficiently make the task for which it was designed. As stated by March and Smith (in March et al, 2008), design refers to the development of artifacts that fulfil objectives.

In other words, design is the key because it extends the organizational capabilities by creating innovative artifacts (Hevner et al, 2004), constructs that allow the development of information systems in companies (March et al, 2008). These artifacts (information systems, in the case of organizations) are produced using methods like the one proposed by Pahl and Beitz in 1995, which consists in the recognition of the need, problem identification, conceptualization, preliminary and definitive solutions and the construction of the final solution.

\section{Multidisciplinary design}

First of all, e-health-business prototypes are designed and developed in a multidisciplinary framework where internet applications design mix with health management and business in a context of knowledge management. Moreover much of the work must be done applying the appropriate research techniques.

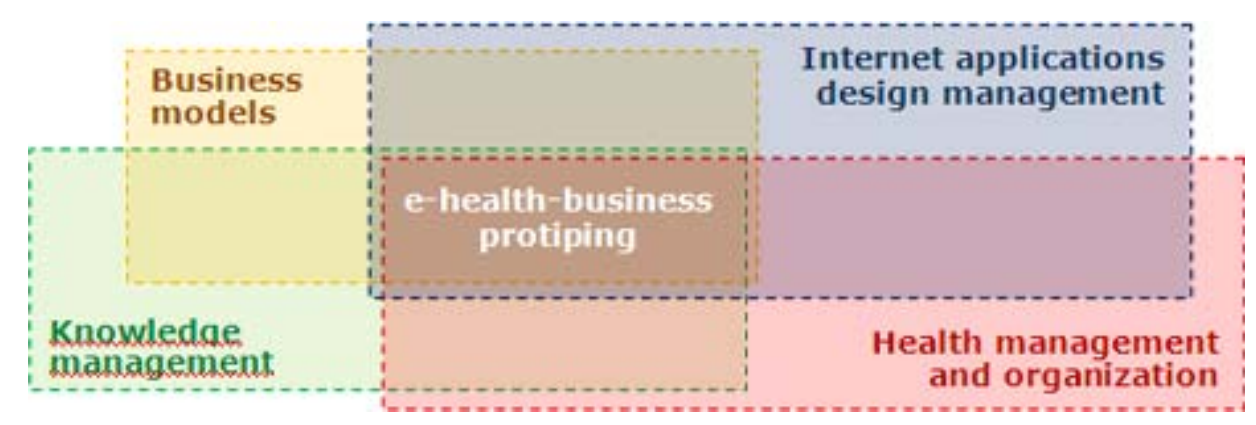


Figure 1. Areas of knowledge that interact to form our field of work

Of the many design methods of information systems that can be found in the literature dedicated to engineering or industrial design (Christopher Alexander, 1971; Nigel Cross, 1984, Christopher Jones, 1984, etc.), the one proposed by Pahl and Beitz in 1995 seems more relevant for us and we have relied on it to develop the model for e-health-business prototyping.

Nigel Cross in 1999 classifies design methods into 2 groups: descriptive methods and prescriptive methods. The descriptive models mention the sequence of activities that occur in a design process. The prescriptive, as the name implies, prescribe a pattern of activities, that is, in addition to describing the process, they give guidelines for developing each of the phases and stages of the design process (Chaur Bernal, 2005).

The Pahl and Beitz model belongs to prescriptive models. They propose is to divide the project into different key phases: beginning with the recognition of the needs of the project and identify problems before proceeding to the first creative phase, which is known as 'conceptualization' and which sets out what will be the goal of artifact created. Once we have a clear goal, we try to propose preliminary solutions with low level of detail in the solution and closer to a sketch to the final tool. Once all stakeholders agree that the chosen is the right way, we are ready to do some more definitive solutions and finally develop the end solution, tool or artifact.

The method, as can be denoted, focuses on the so-called "embodiment design" (overall design) and for it proposes a development project by separate functional modules. This has the advantage of simplifying the analysis, but the disadvantage that can arrive to a joint proposal that can be very complex (Syed, Agarwal and Malik, 2000 in Chaur Bernal, 2005).

Our proposal, that has proved usefully in e-health has been developed on the basis of the Pahl and Beitz phases, but emphasising the idea that these phases cycle must be repeated iteratively as often as required. We believe that fulfilling this cycle just once, we may reach a good final solution, but incomplete or likely to receive many changes or amendments once the artifact is already being used by the end user. In each phase we incorporate as a key element the revision of the business model behind the new solution and the the participation of end users as soon and as intensively as possible.

We took inspiration from of authors such as Markus (et al, 2001) and Walls (et al, 1992) that advocate the use of prototypes in the production of artifacts as part of design research. Thus, through the process of incremental development of prototypes, the first one minimizing elements and data nearing the limit of usefulness, but fulfilling the fundamental objective of artifact. The process becomes gradual and the participation of profiles is maximized, allowing to reach a stronger final solution, complete and avoiding content, technological and use errors that reach the end user, which in our case is a patient in therapy for some disease.

\section{MAIN FOCUS OF THE CHAPTER:}

\section{THE INCREMENTAL DESIGN METHOD}

\section{Collaborative design}


From the mentioned above, we propose a new method which has to be considered under the concept of collaborative design, where participants contribute to an interactive design team in order to achieve a common task by sharing experiences, ideas, resources or responsibilities (Ostergaard and Summers, 2009).

The management of design process and tasks consists in delegating them to different profiles of the team involved in the project, getting the artifacts design and the connected new business models a $100 \%$ collaborative process.

It is important to notice that once the project has begun, the client - provider relationship is a secondary factor, and from now everybody is assigned at one of the tree teams which will interact during all the design, development and implementation process according to their profile.

\begin{tabular}{|l|l|}
\hline Business Team & $\begin{array}{l}\text { Leading and management of the project. } \\
\text { End-user and stakeholders relationship. }\end{array}$ \\
\hline Design Team & $\begin{array}{l}\text { Creative proposals, for contents and interfaces. } \\
\text { Management of tests and assessments. }\end{array}$ \\
\hline Technical Team & Implementation according to design requirements and specifications. \\
\hline
\end{tabular}

This team division is in fact nominal, because actually in a collaborative multidisciplinary team, members, information and resources can be distributed across different geographic, organizational, or time limits (Ostergaard and Summers, 2009). Particularly, the team that has worked in the prototypes is based in Spain, but with contributions from work teams installed in Portugal and Mexico.

\section{Design phases, cycles and work flow}

The method follows 5 phases and each of the phases has a cycle of 5 steps and each step has an elemental Work Flow.

\section{Phases}

\begin{tabular}{|l|l|}
\hline 1. Problem & $\begin{array}{l}\text { Identification of the need, recognizing the problem. General aim. } \\
\text { First agreement of all stakeholders. }\end{array}$ \\
\hline 2. Concept & $\begin{array}{l}\text { Conceptual proposal and specific aims. } \\
\text { First agreement of all team members. } \\
\text { First draft of the prototype and the business model }\end{array}$ \\
\hline 3. Proposal & $\begin{array}{l}\text { Creative Proposal as a preliminary solution or as a pre-prototype. } \\
\text { Firs to be contrasted with end users. }\end{array}$ \\
\hline 4. Prototype & $\begin{array}{l}\text { Advanced Creative Proposal with more definition and detail. } \\
\text { First to be tested with end users and repeated one or more times depending on the } \\
\text { results of tests performed. } \\
\text { Final version of the predicted business model. }\end{array}$ \\
\hline 5. Product/service & Final product / service, running and being used by the whole group of end users. \\
\hline
\end{tabular}


First to apply the new business model.

\section{Steps}

In each of the 5 phases a cycle of 5 steps is followed. Each steps more or less relevant in each the phases as well as the phases should be repeated one or more times.

\begin{tabular}{|c|c|c|c|}
\hline & Idea & Leading & Relevant \\
\hline 1. Agreement & $\begin{array}{l}\text { Is not referred to the } \\
\text { contracts but to the fact that } \\
\text { the people involved in the } \\
\text { process of design and } \\
\text { development agrees } \\
\text { regularly on what they are } \\
\text { doing and the focus of the } \\
\text { work. }\end{array}$ & $\begin{array}{l}\text { Problem: } \\
\text { Ensuring that we share } \\
\text { the problem to be solved } \\
\text { in an entirely way and } \\
\text { how this problem is an } \\
\text { opportunity to test a new } \\
\text { business model. }\end{array}$ & $\begin{array}{l}\text { Concept: } \\
\text { Ensure that the solution } \\
\text { that is visualized meets } \\
\text { the expectations set. } \\
\text { Prototype: } \\
\text { Ensure that the artifact } \\
\text { complies effectively with } \\
\text { the aims set at project } \\
\text { beginning. }\end{array}$ \\
\hline 2. Documentation & $\begin{array}{l}\text { Every effort should be } \\
\text { documented to establish } \\
\text { certain variables of } \\
\text { knowledge management. } \\
\text { This is for the following } \\
\text { phases and other projects. }\end{array}$ & $\begin{array}{l}\text { Concept: } \\
\text { A briefing that clearly } \\
\text { establishes the output to } \\
\text { be obtained, the design } \\
\text { and technical criteria as } \\
\text { well as the framework } \\
\text { where the system will fit } \\
\text { when it runs. }\end{array}$ & $\begin{array}{l}\text { Proposal: } \\
\text { All relevant information } \\
\text { must be known and } \\
\text { documented. Non } \\
\text { important data may be } \\
\text { out. }\end{array}$ \\
\hline 3. Resources & $\begin{array}{l}\text { Key resources must be } \\
\text { known and be calculated in } \\
\text { a very precise way. }\end{array}$ & $\begin{array}{l}\text { Product / service: } \\
\text { Description of the key } \\
\text { resources that will be } \\
\text { needed to develop the } \\
\text { real system and from } \\
\text { where these resources } \\
\text { will come from. }\end{array}$ & $\begin{array}{l}\text { Problem: } \\
\text { In the first approach } \\
\text { defines the necessary } \\
\text { resources to meet project } \\
\text { objectives. At this stage } \\
\text { we know if we are able } \\
\text { to continue the } \\
\text { development of the } \\
\text { project. }\end{array}$ \\
\hline 4. System & $\begin{array}{l}\text { The system passes from its } \\
\text { conception to its existence } \\
\text { gradually. }\end{array}$ & $\begin{array}{l}\text { Prototype: } \\
\text { The artifact obtains the } \\
\text { design and techniques } \\
\text { features necessary to } \\
\text { achieve the main of the } \\
\text { project. The user should } \\
\text { be able to interact with } \\
\text { the artifact without } \\
\text { problems. }\end{array}$ & $\begin{array}{l}\text { Proposal: } \\
\text { Is in the proposal stage } \\
\text { where the conceptual } \\
\text { definition of the artifact } \\
\text { is finished and from } \\
\text { there it will direct the } \\
\text { project. } \\
\text { Product/service: }\end{array}$ \\
\hline
\end{tabular}




\begin{tabular}{|l|l|l|l|}
\hline 5. Test & & $\begin{array}{l}\text { In this phase the artifact } \\
\text { must be in optimal } \\
\text { condition to be tested by } \\
\text { the total number of users } \\
\text { and to go out to the } \\
\text { market. }\end{array}$ \\
\hline & $\begin{array}{l}\text { Normally, thanks to the test } \\
\text { the agreement is closed. }\end{array}$ & $\begin{array}{l}\text { Proposal: } \\
\text { The key test is the one } \\
\text { conducted with the first } \\
\text { operative prototype, } \\
\text { under a rigorous research } \\
\text { protocol. }\end{array}$ & $\begin{array}{l}\text { Problem: } \\
\text { Testing the significance } \\
\text { of the problem from } \\
\text { other points of view, } \\
\text { analyzing alternative } \\
\text { solutions and asking to } \\
\text { experts in the field, this } \\
\text { should help to correct the } \\
\text { asymmetries in the points } \\
\text { of view of different } \\
\text { professional profiles. }\end{array}$ \\
\hline
\end{tabular}

\section{The whole process}

All steps are present and important in all the phases of the process, for instance sometimes problems are so complex and the points of view so different that a simple graphical model should help to make in common the problem to be solved and this would be the role of the system (step n.4) in the problem phase. Anyway some of them may be highlighted as leading and as relevant steps in each phase of the process. The following table summarises what has been exposed previously.

\begin{tabular}{|l|l|l|l|l|l|}
\hline Phases / Steps & Agreement & Documentation & Resources & System & Test \\
\hline 1 Problem & Leading & & Relevant & & Relevant \\
\hline 2 Concept & Relevant & Leading & & & Relevant \\
\hline 3 Proposal & & Relevant & & Relevant & Leading \\
\hline 4 Prototype & Relevant & & & Leading & Relevant \\
\hline 5 Product/service & & & Leading & Relevant & Relevant \\
\hline
\end{tabular}




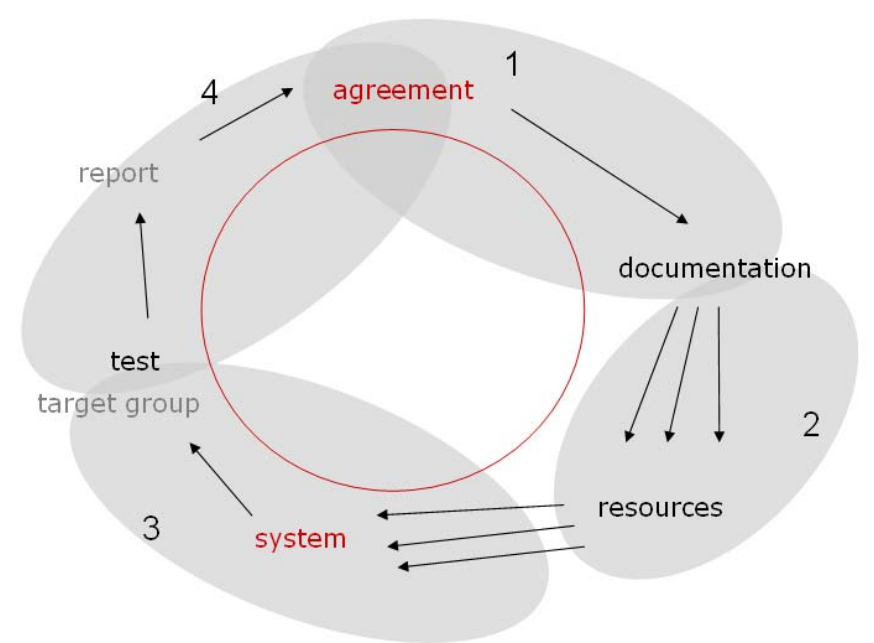

Fig.1. STAGES of the Incremental Design Method of Systems

The process begins with an agreement that comes from the precedent phase, except for the phase 1 , Problem. Following the agreement is documentation, that specifies all the information needed in each of the phases the basic components to start producing what will be the first prototype of the artifact, a very preliminary version of it, in which with the minimum elements can fulfill the main objective of the project.

With the first version of the prototype we can start drawing the exploitation protocol, which ultimately will help us to know the system requirements that will be implemented in the artifact, hardware or software tools that must be available by the user and/or customer and also the identification of the skills needed by the end user of the artifact to interact with him.

At this stage it is also possible to identify a first target group -a sample of what will be the end user audience- to serve as a real user and interact directly with the prototype. This first interaction or approach with the artifact is what we call Test. In it, the user should be able to comply, with the minimum elements that this first prototype offers, the overall objective of the project. Once the first test has been made, it is possible to draft a report with data collected in the test. With these data it is possible to reach the following agreement between profiles, recognize needs, specifications and details (technical, content and usage), unknown at this moment and, on that basis, advance to the next PHASE of the project, which increase the detail in each STEP, in order to make the tests with a target group with new features and which interact with a prototype artifact with a higher level of detail.

Finally it is necessary to consider that the each step in each phase follow an elemental work flow determined by four key concepts or elements: Profile, Task, Product and Approval (fig 2) 


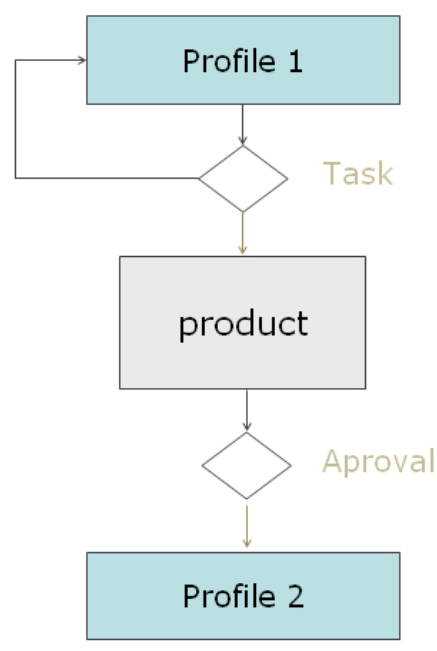

Fig.1.WorkFlow used by LAM-UPC in our diary work

\section{Workflow explanation}

Each PROFILE has an assigned TASK in each phase of the project, which must end with the delivery of so called PRODUCT which varies according to the profile of each person. So, someone in the Management area will develop a document or contract, as a person of the Design area may submit a sketch design of product, a user interface or an animation. The latter concept, the APPROVAL consists in that every product must have the approval of the team, especially from the area manager and the team leader.

\section{Exemplification of the incremental design method of systems: E-DIS project}

We present hereafter the instantiation of our design method in the process of design, development and implantation of E-DIS, an e-health system already in operation in the "Hospital de Sant Pau" in Barcelona. E-DIS is a telemedicine system that aims to change the model of the treatment of oropharyngeal dysphagia of neurological origin through the use of information technology. The part of the treatment that is replaced by E-DIS is related to oropharyngeal praxis. Patients who carry out this part of the treatment watch several videos where the doctor performs the exercises and gives specific instructions for proper performance. Once mastered the exercise, the patient records each exercise on video and sends it through the system so that the person responsible for implementing therapy review and make its recommendations (Bascuñana, et al, 2009).

The hypothesis is that use of the E-DIS system is comparable to conventional therapy in terms of patient outcomes. The E-DIS system should allow:

1) That more patients access to treatment: Is estimated that through the E-DIS system a speech therapist may review up to three times more patients at the time of a conventional session (1 hour).

2) Reduce the cost of treatment with regard to conventional therapy.

3) A clinical outcome comparable to conventional therapy.

4) The added benefit of facilitating and possibly improve the clinical work (Bascuñana, et al, 2009). 


\section{Aplication of Incremental Design Method}

\section{Phase 1: Problem}

\begin{tabular}{|l|l|}
\hline Phase 1 Aim & $\begin{array}{l}\text { Acknowledge the problem to solve, what is the target of the project and what is the } \\
\text { aim to be met by the artifact to be developed. }\end{array}$ \\
\hline Task Assignment & $\begin{array}{l}\text { In this phase the main task is assigned to the Business Team in conjunction with the } \\
\text { client or partner involved in the project, who knows the need and how it should be } \\
\text { met. The task of the Business Team is, in the first instance, to recognize if we can } \\
\text { meet the requirements of the customer or partner and, then, identify how the project } \\
\text { aim can be met in the most efficient possible way. }\end{array}$ \\
\hline $\begin{array}{l}\text { Implementation } \\
\text { in the E-DIS } \\
\text { project }\end{array}$ & $\begin{array}{l}\text { In the case of E-DIS project, the need was to facilitate the praxis to patients and to } \\
\text { reduce costs involved in carrying out the dysphagia therapy in the hospital or } \\
\text { medical center. } \\
\text { The dysphagia patients are people with some degree of neurological damage and the } \\
\text { costs of moving from home to hospital is too high. Besides, another problem is } \\
\text { given by the inefficiency that means for medical personnel attend only 2 patients per } \\
\text { hour at fixed schedules. } \\
\text { Then the project aim was to create a system that would, at the beginning, to } \\
\text { maximize the time of the therapist in patient care and, secondly, reduce the } \\
\text { economic costs for both the patient and the health system. The initial aim was to } \\
\text { allow the medical staff to review the exercises performed by the patient from their } \\
\text { PC and then to provide medical advice and suggestions. }\end{array}$ \\
\hline Conclusion & \begin{tabular}{l} 
From this point, the Design and Technical Area are able to start the creative work. \\
\hline
\end{tabular}
\end{tabular}

Phase 2: Concept

\begin{tabular}{|l|l|}
\hline Phase 2 Aim & $\begin{array}{l}\text { Propose a conceptual solution to the problem by identifying the aims that must be } \\
\text { reached by the artifact }\end{array}$ \\
\hline Task Assignment & $\begin{array}{l}\text { At this phase all branches of the team collaborate, including customer or project } \\
\text { partner, because in this phase we try to generate ideas and proposals that will form } \\
\text { the basis of the project. }\end{array}$ \\
\hline $\begin{array}{l}\text { Implementation } \\
\text { in the E-DIS } \\
\text { project }\end{array}$ & $\begin{array}{l}\text { For E-DIS the conceptual proposal was simple and concrete. As a general aim we } \\
\text { need the patient to be able to send video by Internet so the therapist could review it } \\
\text { and decide whether the exercise was properly performed. The specific aim was to } \\
\text { ensure proper recording of the video by the patient and its subsequent transmission. } \\
\text { Technically, the goal was clear: We needed to record digital video, we needed the } \\
\text { patient to attach a video file and we needed the therapist received the video in his } \\
\text { mailbox. }\end{array}$ \\
\hline Conclusion & $\begin{array}{l}\text { At the end of this phase, the team is confident to meet the main and can start finding } \\
\text { the best solutions to the problem. }\end{array}$ \\
\hline
\end{tabular}




\section{Phase 3: Proposal}

\begin{tabular}{|c|c|}
\hline Phase 3 Aim & $\begin{array}{l}\text { The initial proposal consists in what can fulfill the main aim of the artifact with the } \\
\text { minimum elements. }\end{array}$ \\
\hline Task Assignment & $\begin{array}{l}\text { In this phase the tasks are divided between the Business Team, which fully meets } \\
\text { the aim to be met by the proposal; the Design Team, which should make the user } \\
\text { with minimal elements fulfilling the aim of the project; and the Technical Team, } \\
\text { which should begin to identify technological needs that the project must satisfy. }\end{array}$ \\
\hline $\begin{array}{l}\text { Implementation } \\
\text { in the E-DIS } \\
\text { project }\end{array}$ & $\begin{array}{l}\text { In this case, we had all the tools at our fingertips. From the point of view of content, } \\
\text { we needed the doctor to teach patients how to perform the exercise. Using a } \\
\text { conventional video camera we filmed the doctor performing the exercises and we } \\
\text { edit it on a DVD, which later the patient could see on his computer or on his DVD } \\
\text { player. In a parallel way, the medical team was looking for } 4 \text { or } 5 \text { patients who form } \\
\text { the initial target group. At this early stage they found a group of patients with } \\
\text { different levels of neurological damage and who count with the necessary } \\
\text { technological tools in their home. This was an Internet-connected computer } \\
\text { equipped with a Webcam. The next stage of the Work Flow was initial testing. In } \\
\text { these tests we noticed how the patient could see a doctor to perform the exercises } \\
\text { and then he was able to repeat by himself or assisted by a relative or carer. } \\
\text { Obviously, in patients with high neurologic damage the test outcome was less } \\
\text { successful than in patients with low level of damage, because it is too difficult to } \\
\text { them to keep the focus on an activity and to understand that he was undergoing tests. } \\
\text { Thanks to these tests we were unable to determine that in those patients with high } \\
\text { neurologic damage is essential to help a family member or assistant carer. In } \\
\text { technical terms, we determined that the recorded video must have very special } \\
\text { characteristics in order to be sent over the Internet without data transfer problems. } \\
\text { With this preliminary solution we note that the project aim could meet with the } \\
\text { minimum available elements. We get the patient not to move from his home and, } \\
\text { with this, we get the expected cost savings. If we consider that for each therapy } \\
\text { session the patient's family must pay an ambulance or special taxi that takes him to } \\
\text { the hospital, spending at least } 3 \text { or } 4 \text { hours to going to the hospital, do therapy and } \\
\text { going back to home, we believe that the aims are met favourably. From these tests } \\
\text { was possible, with the medical team, to determine the next steps, both technical } \\
\text { point of view -the artifact in its next version should meet certain technical } \\
\text { requirements and interaction with the patient- and medical standpoint -to more } \\
\text { accurately determine which patients were most suitable for further testing. }\end{array}$ \\
\hline Conclusion & $\begin{array}{l}\text { At the end of this phase, the team is certain that the technological resources } \\
\text { necessary to carry out the project exist. }\end{array}$ \\
\hline
\end{tabular}

Phase 4: Prototype

\begin{tabular}{|l|l|}
\hline Phase 4 Aim & To produce an enhanced version of the artifact, even in prototype level, but close to
\end{tabular} the final solution. 


\begin{tabular}{|c|c|}
\hline Task Assignment & $\begin{array}{l}\text { In this phase the most work is on the Design and Technical teams, because it is } \\
\text { where the artifact must to be highly developed. It is the phase that involves more } \\
\text { work, because we passed from a solution almost sketch-level to an implementation } \\
\text { close to the final artifact. In the stage of testing and reporting, customer or project } \\
\text { partner must also have an important participation by providing conclusions from } \\
\text { their views and interests. }\end{array}$ \\
\hline $\begin{array}{l}\text { Implementation } \\
\text { in the E-DIS } \\
\text { project }\end{array}$ & $\begin{array}{l}\text { For this phase we developed a Web application that would integrate all profiles } \\
\text { involved in the system. We managed a database of doctor profile -responsible of } \\
\text { general therapy-, therapist profile -manager of a group of patients- and patient } \\
\text { profile. } \\
\text { The medical team considered good the possibility of grouping the patients into } 4 \text { or } \\
5 \text { people and put them in charge of a therapist. The doctor responsible for the } \\
\text { therapy plays a role of supervisor throughout the process. From a design standpoint, } \\
\text { the application proposed a graphical user interface to enable all profiles interact } \\
\text { seamlessly with the artifact. The whole process of exercise could be done within the } \\
\text { application. Each person had a user name and password, and once inside, could } \\
\text { perform tasks assigned to him. Thus the patient could come in, check which session } \\
\text { has to perform, -of a total of } 15-\text {-, review the videos that the doctor had prepared for } \\
\text { each exercise and perform by himself/herself or assisted by a carer. Subsequently, } \\
\text { the system allows attach and send the video made. The recorded video came directly } \\
\text { to the profile page of the therapist to whom the patient was assigned. So, he could } \\
\text { review the exercise performed by the patient and comment approval or tips to } \\
\text { improve the practice face the next day of therapy. } \\
\text { In this case, the target group consisted of } 15 \text { patients, again selected by the medical } \\
\text { responsible, and the test period was } 15 \text { days in which the patient should send every } \\
\text { day the amount of videos due to him/her. At this phase we found new problems, for } \\
\text { example, the stress can cause an information system in people of certain age } \\
\text { (resistance to change) and problems of use and interaction of some patients with the } \\
\text { Web application. We note that the system should be even simpler, both in access to } \\
\text { information as to the tasks the patient and therapist should meet within the system. } \\
\text { For these findings is currently working on what would be the Phase } 4.1 \text {, refining the } \\
\text { last details of the prototype and hoping that the proposal is as close as possible to the } \\
\text { final solution to be tested by a group of users in many much higher. It is estimated } \\
\text { that the test may involve other hospitals locally and reach the amount of } 150 \\
\text { patients. }\end{array}$ \\
\hline Conclusion & $\begin{array}{l}\text { After having completed this phase, the artifact works properly in terms of } \\
\text { technology, content and use to fulfill the aim of the project, but still presents } \\
\text { problems to the end user on interaction and usability issues and certain levels of } \\
\text { content still in process of definition. }\end{array}$ \\
\hline
\end{tabular}

\section{Phase 5: Product/Service}

\begin{tabular}{|l|l|}
\hline Phase 5 Aim & Finish defining the artifact in all design aspects. \\
\hline Task Assignment & At this phase again the main players are the Design and Technical team. The level of \\
\hline
\end{tabular}


detail should reach $100 \%$ and the artifact should not present problems in any aspect. The Business Team must verify that the artifact fully meets the project aims and the client must approve the tool.

Implementation in the E-DIS project
The E-DIS project in this moment is precisely at this phase of development. We are finishing out the details to solve the problems found in the tests of Phase 4 and the project partner for its part is determining the amount and profile of users (patients), which will be needed for the final testing stage.

As in the prototype phase there will be a definitive approach to the final solution, it is expected that after the last test with users on a local level, the artifact is ready to be used and marketed nationally and, at best cases, globally.

\section{Other projects in which it was applied the Incremental Design Method}

As mentioned before, this design method has been tested on 9 projects related to knowledge management and online health. We can mention, beside E-DIS system, the following 8 prototyping experiences:

\begin{tabular}{|l|l|}
\hline Project & Aim \\
\hline E-SCHI & $\begin{array}{l}\text { E-SCHI is a project that aims to develop a Web application that enables support in } \\
\text { the treatment of patients with schizophrenia. }\end{array}$ \\
\hline E-TONA & $\begin{array}{l}\text { The E-TONA project is an application for mobile devices that allow control the diet } \\
\text { in overweight teenagers. }\end{array}$ \\
\hline E-FREN & The E-FREN project is a management system of evidence in a medical specialty. \\
\hline CISMA & CISMA is a project to support decision making in primary care mental health. \\
\hline E-FER & Project to support the diagnosis and treatment of wounds. \\
\hline E-PARK & $\begin{array}{l}\text { The E-PARK is a system to support the implementation assisted by a measurement } \\
\text { scale of Parkinson disease. }\end{array}$ \\
\hline E-COGNITIÓN & E-COGNITION is a cognitive rehabilitation system for cognitive impairment. \\
\hline E-TRAN & E-TRAN is a system for monitoring transfusion. \\
\hline
\end{tabular}

\section{PROBLEMS}

The main disadvantage of our design method is at the same time our biggest challenge in the short term. We must work on testing and validation of our proposal by the scientific community of engineering and design. In terms of operational and functional, we believe the method that we developed is consistent in the context we work and so far has brought us significant benefits, such as having the capacity to respond to different problems in the context of e-business and e - health in various projects and do so effectively 
and efficiently. The response to our work we found in the good relationship observed with our customers and partners in different realized and in development projects, but now we have to get the answer in scientific and research terms. It is our lack, but also the next step in our investigation.

\section{FUTURE RESEARCH DIRECTIONS}

In general terms, from our experience we believe that is possible to develop other projects to implement systems of technical support for teams to base their activities in workflows. Our experience shows that the results are favourable, so we believe that this issue can be widely developed in other work fields.

If we think in future research and application possibilities for our proposal, one of the major challenges for our team is open precisely the range of possible economic sectors where our design method of IT artifacts can be applied. So far we have concentrated on the online health sector because it represents an unexplored world with many possibilities both research and business, but we also want to test our work method in other business sectors that might be benefited by the application of information technologies in their bases of operation. A map of all sectors that can be explored can be drawn and the outlook is encouraging, because we can imagine possible e-business projects in such diverse sectors as construction and food services, but that have as a common denominator that can be affected favourably by IT from their most basic levels (Fig. 3).

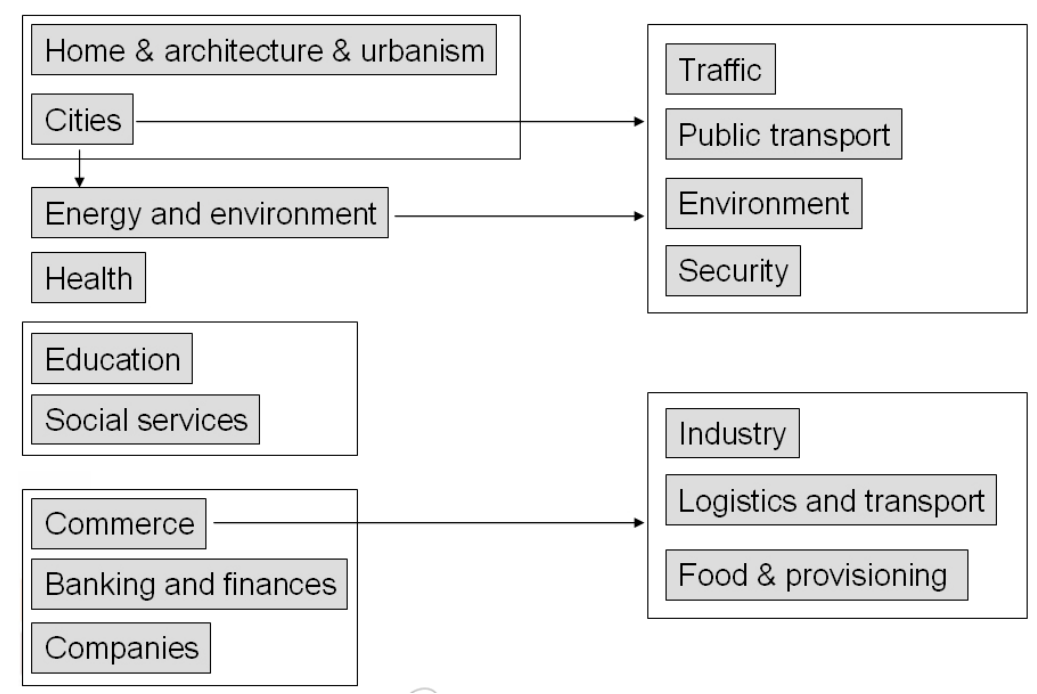

Fig. 3.Map of services which may be affected by Internet and IT

In this sense, we believe in the great possibilities of life "connected". We believe IT will have an important participation in almost all sectors of contemporary society. This will force companies, governments and investment sectors to change their bases and their business strategies to levels that are still unexpected. Perhaps what we know today as e-business is the only possible form of business, what we known as e-health is the only form of health and that everything around us is connected and supported by Internet and communications. In fact, someone already talks about the 'Internet of Things' and some opportunities are emerging to exploit the new network connections. Unfortunately it is not enough how the business models will be in this new era and it is very difficult to hazard something, because even the global stage comes as somewhat nebulous. Nevertheless, we believe efforts will go in that direction, to explore and exploit the use of sensors and devices that enable things are interconnected and through this to discover new business opportunities in sectors hitherto thought. 


\section{CONCLUSIONS}

After our experience in projects in the field of e-business and e-health that have been mentioned in this chapter, the first conclusion that we propose is to highlight the importance of Design in these business areas. Design was recognized as a competitive differentiator element in the industrial production culture, but in the information age emerges as a factor of relevance when managing knowledge and developing innovative solutions in service delivery. Innovation, product of design efforts is probably the most precious resource of the modern economy, in opinion of some authors as Purao (et al, 2008).

In the quest to manage design, we presented our working method called Incremental Design Method for Systems, which until now has been tested in 9 health-related online projects. This method has been proposed with reference to the design method based on phases of Pahl and Beitz (1995), but modified according to our experience in the area of e-business and specifically in e-health. The most striking conclusion of the use of this method is the little time invested in the production of artifacts and how successful the results towards end users, to which the application comes with the bare minimum of content, technological and use errors, due to the iterative conception, design and development process.

Once we find the field that allows us to manage project development opportunities, the next step was to find the best way to manage the workflow between the different profiles that interact in the work team. The search of such a methodology has been working under the premise of "test-mistake", until we find a way to provides better results in terms of effectiveness and efficiency. The results obtained showed that in the 'time' factor we have developed artifacts and set them up using fewer hours of work -compared to previous projects with similar characteristics- and in the 'efficiency' factor we have seen that the results have been satisfactory for the 3 key players in any e-health project: Provider of technology or technological artifact, the client and the end user.

With this method based on cycles of phases that produce prototypes that increase their functionality as progress through the process, we believe that we minimizing the possibility of market failure because the artifact has passed 3 or 4 steps of testing with real users before go out to compete in the market.

We now believe that the method is mature enough to be validated by the scientific and the engineering and design community, from the point of view of science and research, and to be implemented in other business sectors, from the commercial and services point of view. These items are our biggest challenge in the near future. The publication of this chapter is our first step in that long way.

Just today we focus on the health sector, we hope to expand our research capabilities and scope and propose, from other business sectors from the large field of e-business, new views on future deliveries of reports on Internet based business.

\section{REFERENCES}

Adler-Milstein, Julia (2009). Health Care Requires Big Changes to Complement New IT. Harvard Business Review. April 2009.

Pahl, G; Beitz, W. (1995). Engineering Design: A systematic approach; Springer Science and Business media; Springer Verlag; London.

Bascuñana, H; Blanco, B; Rivero, Y; Monguet, J; Muñoz, J; Sampieri, M. (March 2009). A telehealth approach to oropharyngeal dysphagia therapy; Paper presented at the 5th World Congress of International Society of Physical Medicine and Rehabilitation, Istanbul, Turkey, June 14, 2009. 
Bonsiepe, Gui (2000). Una Tecnología Cognoscitiva - De la producción de conocimientos hacia la presentación de conocimientos. Simposium Ricerca+Design, Milano, 2000.

Chaur Bernal, Jairo (2005). Diseño conceptual de productos asistido por ordenador: Un estudio analítico sobre aplicaciones y definición de la estructura básica de un nuevo programa. Doctoral dissertation, Universitat Politècnica de Catalunya, Spain.

Chuan Jun Su (2007). Mobile multi-agent based, distributed information platform (MADIP) for wide-area e-health monitoring; Science Direct; Elsevier.

European Commission, Enterprise \& Industry Directorate General (2008). ICT standards in the health sector: current situation and prospects. Special Study No. 1, 2008; A Sectoral e-Business Watch study by Empirica.

Hollanders, H.; Van Cruysen, A. (2009). Design, Creativity and Innovation: A Scoreboard Approach. Pro Inno. Innometrics.

Herzlinger, Regina ( 2006). Why Innovation in Health Care Is So Hard. Harvard Business Review. May 2006.

Hevner, A.; March, S.; Park, J.; Ram, S. (2004); Design science in information systems research; MIS Quarterly; Vol. 28 No. 1, pp. 75-105.

Maheu, M.; Whitten, P., Allen, A. (2001). E-Health, Telehealth, and Telemedicine. A Guide to Start-up and Success, Jossey-Bass W. Wiley Company.

March, S.; Storey, V. (2008). Design science in the information systems discipline: An introduction to the special issue on design science research. MIS Quarterly Vol. 32 No. 4, pp. 725-730.

Ostergaard, K., Summers, J. (2009) Development of a systematic classification and taxonomy of collaborative design activities. Journal of Engineering Design. February 2009. London, England.

Purao, S; Baldwin, C.; Hevner, A; Storey, V.; Pries-Heje, J; Smith, B.; Zhu, Y. (2008); The Sciences of Design: Observations on an Emerging Field; Working Paper; Harvard Business School.

\section{ADDITIONAL READING SECTION (optional section)}

Bereiter, C. (2002) Design Research for Sustained Innovation; Cognitive Studies, Bulletin of the Japanese Cognitive Science Society, 9(3), 321-327.

Bertola, P.; Teixeira, J. (2002). Design as a knowledge agent: How design as a knowledge process is embedded into organizations to foster innovation; Design Studies 24; 2002; Elsevier Science Ltd.

Candi, Marina (2007). The role of design in the development of technology-based services; Design Studies 24. Elsevier Ltd.

Casadesus-Masanell, R.; Ricart, J. (2007) Competing through Business Models. IESE Business School, University of Navarra; Working Paper; WP no 713; November, 2007. 
Cross, N. (1989). Engineering Design Methods. Wiley, Chichester, Sussex, UK.

Cross, Nigel. (2007). From a Design Science to a Design Discipline: Understanding Designerly Ways of Knowing and Thinking" on the book "Design Research Now. Essays and Selected Projects"; Birkhäuser Verlag AG, Berlín.

Chih-Hsing Chu, Cheng Han-Chung (2007). Business Model Innovation through Collaborative Product Development: A Case Study of Design Services in Taiwan; IEEE; Taiwan.

Johnson, M.; Christensen, C., Kagermann, H. (2008) Reinventing Your Business Model. Harvard Business Review; December, 2008.

Tergan, S.; Keller, T (Eds.) (2005). Visualizing Knowledge and Information: An Introduction; Knowledge and Information Visualization. LNCS 3426, pp. 1 - 23, 2005. Springer-Verlag Berlin Heidelberg.

Youn-Kyung L; Blevis, E.; Stolterman, E. (207) Grand Challenges in Design Research for HumanCentered Design Informatics; D. Schuler (Ed.): Online Communities and Social Computation. HCII 2007, LNCS 4564, pp. 106-115, 2007. Springer-Verlag Berlin Heidelberg.

Younghwa Lee; Kozar, K. (2006); Investigating the effect of website quality on e-business success: An analytic hierarchy process (AHP) approach. Decision Support Systems. Elsevier 